\title{
TECHNICAL EDUCATION - PART OF THE GENERAL EDUCATION IN SLOVAKIA
}

\section{Danka LUKÁČOVÁ}

\begin{abstract}
Technology education is in EU countries considered as an important part of general education of students in primary schools. However, in Slovakia since 2008 we can see gradual degradation of technology education to the current state, which is near total extinction in technical subjects at primary schools. The article describes the gradual development that in Slovakia has led to the current situation and compares it to the technology education of selected EU countries.
\end{abstract}

Key words: technology education, general education

\section{TECHNICKÉ VZDELÁVANIE - SÚČASŤ VŠEOBECNÉHO VZDELÁVANIA NA SLOVENSKU}

Resumé: Technické vzdelávanie je $\mathrm{v}$ krajinách EÚ považované za dôležitú súčast' všeobecného vzdelávania žiakov na základných školách. Na Slovensku však od r. 2008 pozorujeme postupnú degradáciu technického vzdelávania až po súčasný stav, ktorý je blízko úplného zániku technicky orientovaných predmetov na základných školách. Článok popisuje postupný vývoj, ktorý na Slovensku viedol k súčasnému stavu a porovnáva ho s technickým vzdelávaním vybraných krajín EÚ.

Klíčová slova: technické vzdelávanie, všeobecné vzdelávanie

\section{1 Úvod}

Každá vedná disciplína má svoju históriu, vývoj, ktorým prechádzala a rozvíja sa na základe týchto skúseností. Prechádza etapami vel'kého rozmachu a spoločenského uznania, ale aj obdobím nepochopenia a zaznávania, hladania nových riešení problémov, ktoré sú l’udstvu nastol'ované od jeho počiatku. Nie je to inak i v technických disciplínach, nevynímajúc technické vzdelávanie, pretože dejiny l'udstva sú i dejinami techniky.

Vývoj názorov na poňatie obsahu a funkcie technického vzdelávania sa menil v súlade $\mathrm{s}$ celkovým vývojom a poňatím základného vzdelania $\mathrm{v}$ danom období. Tak ako sa menila spoločnost', jej potreby, menil sa aj samotný predmet. Menil sa názov predmetu, $\mathrm{v}$ ktorom sa realizovalo technické vzdelávanie, organizácia a formy jeho vyučovania. V našom článku sa chceme zaoberat' postavením technického vzdelávania na druhom stupni základných škôl na Slovensku po r. 1989.

Ak máme poznat' vývoj technicky orientovaných predmetov na základných školách na Slovensku od roku 1989, je potrebné poukázat' aj na stav pred týmto rokom. Základným predmetom, ktorý mal žiakov orientovat' v technike a formovat' vzt'ah k nej, bol predmet Pracovné vyučovanie.

\section{Pracovné vyučovanie ako povinný predmet od r. 1986}

Pracovné vyučovanie, ako povinný predmet bol súčast’ou učebných plánov, ktoré vstúpili do platnosti schválením Ministerstvom školstva 18. mája 1986. Predmet pracovné vyučovanie bol zaradený vo všetkých ročníkoch druhého stupňa základnej školy s časovou dotáciou dve hodiny týždenne.

Jeho obsah na 2. stupni základnej školy bol zameraný na overovanie teoretických poznatkov, získavanie základných pracovných zručností a návykov z rozličných pracovných oblastí, najmä pri ručnom opracovávaní materiálov, elektrotechnických prácach, pri obrábaní pôdy a pestovaní hospodársky významných rastlín, pri príprave stravy a zhotovovaní výrobkov ručným a strojovým šitím. Žiaci sa mali oboznamovat's poznatkami vedy a techniky, získavat' informácie o výrobe a jej organizácii. Ťažiskom predmetu boli hlavne praktické činnosti žiakov. Obsah 
výchovy a vzdelávania v Pracovnom vyučovaní bol dôsledne polytechnický podla vzoru sovietskej školy a zásad komunistickej výchovy, aj ked' v pedagogickej teórii už polytechnická paradigma ustupovala a nahrádzalo ju humanistické poňatie výchovy a vzdelávania (Škoda, Doulík, 2009). Štruktúra Pracovného vyučovania na 2. stupni základnej školy členila predmet do troch zložiek: technické práce, pestovatel'ské práce a špecifická príprava dievčat. Zložky pracovného vyučovania boli rozdelené do jednotlivých ročníkov od piateho po ôsmy a žiaci ich absolvovali rozdelení podla pohlavia.

Učebné osnovy technických prác uvádzali všeobecné výchovno-vzdelávacie ciele pre ročníky 5 až 8 . Boli zamerané na praktické osvojenie základných zručností s nástrojmi, náradím pri opracovávaní dreva, kovov, plastov a pri zostavovaní jednoduchých elektrických obvodov. Žiaci mali zvládnut' riešenie jednoduchých technických problémov, osvojit' si základné technické pojmy, poznat' rôzne druhy povolaní. Dôraz sa tiež kládol na rozvoj zručností pri technickej záujmovej činnosti.

Osnovy celého Pracovného vyučovania niesli výraznú pečat' socialistickej výchovy. Vo vtedajšom ponímaní išlo o spojenie školy $\mathrm{s}$ robotníckou triedou. Túto situáciu $\mathrm{v}$ roku 1996 kritizoval Krušpán, ktorý za najväčšiu chybu považoval orientáciu zložky technické práce (práce $v$ dielňach)

na výrobu a preferovanie manuálnych pracovných zručností (Krušpán, I., 1996). Pokusom o prvú zmenu boli učebné osnovy Pracovného vyučovania zverejnené s úpravou učebných plánov v roku 1991.

\section{Nová koncepcia technického vzdelávania po roku 1989}

Nová koncepcia technického vzdelávania bola navrhnutá hned' po roku 1989. Odborníci navrhli zmeny $\mathrm{v}$ učebnom pláne a v osnovách jednotlivých predmetov. Základné školstvo realizovalo výučbu podl'a zmeneného učebného plánu od roku 1991. V ňom problematiku technického vzdelávania zastupoval predmet Pracovné vyučovanie.

Predmet Pracovné vyučovanie na základnej škole po roku 1989 bol charakterizovaný osnovami ako významná súčast' všeobecného polytechnického vzdelávania, ktorá utvára u žiakov kladný vzt'ah k práci, poskytuje základné výrobné a technické vedomosti, zručnosti a návyky $\mathrm{z}$ rôznych oblastí pracovných činností, utvára predpoklady na spojenie vyučovania s výrobou a produktívnou prácou. Učil žiakov samostatne a tvorivo pracovat' a viest' ich $\mathrm{k}$ základnej orientácii na d’alšie vzdelávanie a vol'bu povolania. Rozvíjal u nich záujem o vedu a techniku, o modernú priemyselnú a pol’nohospodársku výrobu a ostatné nevýrobné oblasti národného hospodárstva. Formoval ich morálno - vôl'ové vlastnosti ako je ciel'avedomost', pracovitost', vytrvalost', kritickost', sebakritickost' a vedomie zodpovednosti za výsledky svojej práce. Pracovné vyučovanie rozvíjalo osobnost' žiaka a utváralo predpoklady na zapojenie sa do spoločensky prospešnej práce, technickej, pestovatel'skej a d’alšej záujmovej činnosti. Tieto zámery sa uskutočňovali $\mathrm{v}$ troch zložkách Pracovného vyučovania: v technických prácach, pestovatel'ských prácach a $\mathrm{v}$ špecifickej príprave dievčat. Je zaujímavé, že $\mathrm{v}$ týchto učebných osnovách nad’alej zotrvávala orientácia na polytechnické vzdelávanie rovnako ako pred rokom 1989.

V roku 1995 prebehla už v samostatnej Slovenskej republike transformácia vyučovacích predmetov vo forme zmeny učebných osnov jednotlivých predmetov. $\mathrm{Na}$ druhom stupni základnej školy k zásadným zmenám vobsahu vyučovania neprišlo, podstatná bola transformácia názvu predmetu na Technickú výchovu. Ovel’a zásadnejšia zmena nastala na prvom stupni základnej školy, kde sa Pracovné vyučovanie v 1. a 2. ročníku integrovalo do Výtvarnej výchovy.

Prelomovým rokom v technickom vzdelávaní sa stal rok 1997, kedy bola základná škola rozšírená o deviaty ročník. Do platnosti vstúpili nové učebné plány $\mathrm{v}$ troch základných variantoch, pričom v každom malo technické vzdelávanie rovnaké zastúpenie v počte hodín. Predmet sa nazýval Technická výchova a vo všetkých variantoch sa vyučoval rozsahu jedna hodina týždenne vo všetkých ročníkoch druhého stupňa základných škôl. V d'alšom popíšeme tzv. klasický variant, ktorý základné školy použivali na výučbu Technickej výchovy najčastejšie.

Učebné osnovy Technickej výchovy, ktoré vstúpili do platnosti v septembri 1997, obsahovali tri zložky. Boli to technická výchova, pestovatel'ské práce a rodinná 
príprava. Učivo $\mathrm{v}$ zložke technická výchova bolo rozdelené na základné a alternatívne. Označenie „alternatívne“ učivo bolo chápané v zmysle „rozširujúce”, pretože obsah tohto učiva bol vopred určený, netvoril teda alternatívu v plnom význame slova. Základné učivo malo byt' $\mathrm{v}$ plnom rozsahu prebrané na každej základnej škole, rozširujúce učivo len tam, kde učitel' rozhodol, že má podmienky pre jeho kvalitnú výučbu. Rozsah základného učiva zložky technická výchova bol 13 hodín ročne.

\section{Technické vzdelávanie po reforme v r. 2008}

Obsah a organizácia vzdelávania na základných školách sa podla zákona z r. 2008 riadi štátnym vzdelávacím programom (ŠVP). ŠVP obsahuje rámcový model absolventa, rámcový učebný plán školského stupňa, rámcové učebné osnovy. Rámcový učebný plán pre ZŠ s vyučovacím jazykom slovenským je rozdelený do vzdelávacích oblastí: Jazyk a komunikácia, Príroda a spoločnost', Človek a príroda, Človek a spoločnost', Človek a hodnoty, Matematika a práca $\mathrm{s}$ informáciami, Človek a svet práce, Umenie a kultúra, Zdravie a pohyb. Technické vzdelávanie sa prednostne realizuje vo vzdelávacej oblasti Človek a svet práce v troch predmetoch: Pracovné vyučovanie na 1. stupni ZŠ, Svet práce a Technika na 2. stupni ZŠ. Z $Z$ tejto skupiny je však nutné vyňat' predmet Svet práce, ktorého obsah je smerovaný do tvorby a ochrany životného prostredia prostredníctvom problematiky starostlivosti o trávnik, záhradu, pestovanie rastlín a pod., čo s technickým vzdelávaním nesúvisí. Nesúhlasí tiež s názvom predmetu, ktorý by mal byt' zameraný skôr na problematiku výberu strednej školy, vol'by povolania, uplatnenia na trhu práce. (Lukáčová, 2010).

Štátom garantované technické vzdelávanie podl'a tohto vzdelávacieho programu kleslo na dve hodiny týždenne za celú základnú školu (vo 4. ročníku 1 hodina, v 7. alebo 8. ročníku 1 hodina).

Tabul'ka 1 Porovnanie počtu hodín technického vzdelávania na základných školách od r. 1986

\begin{tabular}{|l|l|l|}
\hline Rok & $\begin{array}{l}\text { Názov } \\
\text { predmetu }\end{array}$ & $\begin{array}{l}\text { Počet hodín } \\
\text { v učebných } \\
\text { plánoch }\end{array}$ \\
\hline
\end{tabular}

\begin{tabular}{|l|l|l|}
\hline & & $\begin{array}{l}\text { v ročníkoch 5.- } \\
8 .(9 .)\end{array}$ \\
\hline 1986 & $\begin{array}{l}\text { Pracovné } \\
\text { vyučovanie }\end{array}$ & 8 \\
\hline 1991 & $\begin{array}{l}\text { Pracovné } \\
\text { vyučovanie }\end{array}$ & 6 \\
\hline 1997 & $\begin{array}{l}\text { Technická } \\
\text { výchova }\end{array}$ & 5 \\
\hline 2008 & Technika & 1 \\
\hline
\end{tabular}

S týmto počtom hodín kleslo Slovensko na poslednú priečku $\mathrm{v}$ technickom vzdelávaní na základnej škole medzi krajinami ako Nemecko, Fínsko, Švédsko, Česká republika, Anglick a Wales, Mad'arsko, Pol'sko.

Vzhl'adom na uvedenú nízku časovú dotáciu je vel'mi t'ažké porovnávat' obsahy, ktoré sú zaradené do predmetov technického zamerania. V tabul'ke 2 sme sa preto pokúsili porovnat' aspoň názvy predmetov, $\mathrm{v}$ ktorých sa realizuje technické vzdelávanie a počty hodín vyjadrené $\mathrm{v}$ hodinovej dotácii za jeden týždeň na druhom stupni základnej školy.

\section{Porovnanie technického vzdelávania na základných školách na Slovensku a v zahraničí}

Technické vzdelávanie a aj iné typy vzdelávania sú $v$ rôznych krajinách rôzne ponímané, čo je dané ich historickým a spoločenským vývojom. Je zrejmé, že aj problematika kurikula je ovplyvňovaná sociálnymi, ekonomickými a politickými potrebami a ciel'mi. V krajinách ako Anglicko a Wales, Švédsko, Fínsko má kurikulum formu zákona a je teda záväzné pre všetky školy poskytujúce základné vzdelanie. V iných krajinách (Nórsko, Holandsko) je centrálne určené len rámcové kurikulum, ktorého naplnenie je v kompetencii škôl. Napriek rozličnému prístupu $\mathrm{k}$ tvorbe kurikúl však môžeme sledovat' $\mathrm{v}$ jednotlivých učebných plánoch krajín dôraz na technické predmety. Najlepšie to vidiet' na počtoch hodín, ktoré žiaci absolvujú v priebehu školskej dochádzky na druhom stupni.

Tabul'ka 2 Porovnanie počtu hodín technického vzdelávania na základných školách vo vybraných krajinách

\begin{tabular}{|l|l|l|l|}
\hline Krajina & $\begin{array}{l}\text { Názov } \\
\text { predmetu } \\
\text { (slovenský } \\
\text { preklad) }\end{array}$ & $\begin{array}{l}\text { Názov } \\
\text { predmetu } \\
\text { (pôvodný) }\end{array}$ & $\begin{array}{l}\text { Počet } \\
\text { hodín za } \\
\text { týždeň }\end{array}$ \\
\hline Nemecko & $\begin{array}{l}\text { Pracovné } \\
\text { vyučovanie } \\
\text { Práce } \\
\text { v dielňach } \\
\text { Technicko- }\end{array}$ & Arbeitslehre & $1-2$ \\
\hline
\end{tabular}




\begin{tabular}{|l|l|l|l|}
\hline & $\begin{array}{l}\text { priemyseln } \\
\text { á } \\
\text { oblast' }\end{array}$ & & \\
\hline Fínsko & Zručnosti & Slöjd & 3 \\
\hline Švédsko & Zručnosti & Technology & $5-9$ \\
\hline $\begin{array}{l}\text { Česká } \\
\text { republika }\end{array}$ & $\begin{array}{l}\text { Clovek } \\
\text { a svet práce }\end{array}$ & $\begin{array}{l}\text { Člověk a svět } \\
\text { práce }\end{array}$ & $\begin{array}{l}3 \text { za celý } 2 . \\
\text { stupeň }\end{array}$ \\
\hline $\begin{array}{l}\text { Anglicko } \\
\text { a Wales }\end{array}$ & $\begin{array}{l}\text { Dizajn a } \\
\text { technika }\end{array}$ & $\begin{array}{l}\text { Design and } \\
\text { Technology }\end{array}$ & $1-1,5$ \\
\hline $\begin{array}{l}\text { Mad'arsko } \\
\text { Spôsob } \\
\text { života } \\
\text { a praktické } \\
\text { poznatky } \\
\text { (Technika) }\end{array}$ & $\begin{array}{l}\text { Eyakorlati } \\
\text { ismeretek }\end{array}$ & $1-3$ \\
\hline Pol'sko & Technika & Technika & 2 \\
\hline $\begin{array}{l}\text { Slovenská } \\
\text { republika }\end{array}$ & Technika & Technika & $\begin{array}{l}1 \text { za celý } 2 . \\
\text { stupeň }\end{array}$ \\
\hline
\end{tabular}

Pri pohl'ade na čísla v tabul'ke 2 je jasné, že technickému vzdelávaniu na základných školách nie je na Slovensku venovaná taká pozornost' ako vo vyspelých krajinách EÚ.

Väčšina vyspelých krajín EU si stanovila za základný ciel' mat' vyučovací predmet, prostredníctvom ktorého žiaci získajú základnú orientáciu v oblasti techniky, aby sa mohli zaradit' do modernej spoločnosti ako plnohodnotní občania (Kožuchová, Pavelka, 2007, s. 168). Z porovnania záverečnej fázy vývoja technického vzdelávania $\mathrm{V} \quad \mathrm{SR}$ s krajinami EÚ je badatel'ný výrazný rozdiel. Vývoj v SR má klesajúcu tendenciu, zatial' čo v krajinách EÚ má smerovanie rozvojový charaktera sleduje spoločenské požiadavky.

\section{Záver}

Hoci krajiny EÚ sú oddelené geograficky a ich kultúry sa tiež líšia, existuje niekol'ko podobných funkcií $\mathrm{v}$ ich učebných ciel'och, metódach a obsahu. Napríklad technická gramotnost' je $\mathrm{v}$ nich univerzálnym ciel'om. $\mathrm{V}$ hodnotení vzdelávania $\mathrm{v}$ krajinách EÚ nachádzame aj d'alšie zjednocujúce ciele: pochopenie úlohy vedy a techniky v spoločnosti, rovnováha medzi technológiou a životným prostredím, rozvoj zručností ako je plánovanie, realizácia, hodnotenie, sociálne (morálne) etické myslenie, inovatívnost', povedomie, flexibilita a podnikanie. Najvýznamnejšou súčast'ou vzdelávacích obsahov sú: technológie, profesie $\mathrm{v}$ technike a priemysle, bezpečnostné postupy, ergonómia, dizajn, konštrukcia techniky, hodnotenie výsledkov práce, história techniky, schopnost' riešit' problémy, hodnotiace stratégie a vzt'ah medzi spoločnostou a prírodou (Kozík a kol, s. 26).
Krajiny reagujú vo svojich vzdelávacích programoch na text Lisabonskej stratégie 2, ktorá akcentuje prechod k ekonomike a spoločnosti založenej na znalostiach prostredníctvom lepších politík na podporu výskumu, vývoja a inovácií, štrukturálnych reforiem podporujúcich konkurencieschopnost' a dotvorením vnútorného trhu. Zdôrazňuje sa tak dôležitost' zvyšovania úrovne vzdelávania a prípravy pre život $\mathrm{v}$ informačnej spoločnosti (Lisabonská stratégia, 2000). Stratégia Európa 2020 si vytýčila ciel' inteligentný rast, t. j. rozvoj ekonomiky založenej na znalostiach a inováciách spojených $\mathrm{s}$ udržatel'ným rastom, t. j. podporou konkurencieschopnejšej a ekologickejšej ekonomiky menej náročnej na zdroje (Stratégia Európa 2020).

Týmto potrebám sa do určitej miery prispôsobuje školstvo, ked' dnešní absolventi technických škôl dostávajú ovel'a komplexnejšie vzdelanie ako pred rokmi. Nebezpečenstvom pre úroveň odborných vedomostí technikov je okliešt'ovanie odborného vzdelávania. Koncepcia technického vzdelávania, ktorá bola vytváraná niekol'ko desiatok rokov, je požiadavkou na zjednotenie vzdelávania a stratégií $\mathrm{v}$ technike a technológiách, nie snahou na znižovanie úrovne technickej spoločnosti (Serafín, 2014, s. 8).

Zostáva verit', že súčasná snaha Štátneho pedagogického ústavu, ktorý inicioval inováciu rámcového učebného plánu $\mathrm{z} \mathrm{r} .2008$ aj $\mathrm{s}$ ciel'om posilnenia technických a prírodovedných predmetov, bude tieto požiadavky reflektovat' a nájde podporu učitel'ov, odbornej aj laickej verejnosti na realizáciu v praxi.

\section{Literatura}

[1] KOZÍK, T. a kol.: Analýza a zdôvodnenie revízie vzdelávacej oblasti Človek a svet práce. In: Učitel'ské noviny: dvojtýždenník o školstve a vzdelávaní, 2013. ISSN 0139-5769, roč. 60, č. 11 (2013), s. 25-27.

[2] KOŽUCHOVÁ, M. - PAVELKA, J.: Požiadavky na vedecko-technickú gramotnost absolventa základnej školy. [online]. [cit. 2014-06-25]. Dostupné na: http://www.ped.muni.cz/weduresearch/konfere nce/07kurikulumVpromenachSkoly/CDkurik/c d/studie/pdf/kozuchovapavelka.pdf.

[3] KRUŠPÁN, I.: $\mathrm{K}$ novému obsahu technickej výchovy na 2. stupni ZŠ. In. 
Zbornik Technické vzdelávanie ako súčast' všeobecného vzdelania. Banská Bystrica: UMB, 1996 s. 119. ISBN 80-967957-4-0.

[4] Lisabonská stratégia [online]. [cit. 201406-25]. Dostupné na:

http://www.europskaunia.sk/lisabonska_strate gia

[5] LUKÁČOVÁ, D.: Technické vzdelávanie na Slovensku a školská reforma. 2010. In: JTIE Journal of Technology and Information Education. ISSN 1803-6805, Vol. 2, no. 2 (2010), p. 5-8.

[6] SERAFÍN, Č.: Reflexe technické výchovy v globalizujícím se světě. In Trendy ve vzdélávání. Olomouc: UP, 2014, s. 5 - 12. ISSN 1805-8949

[7] Stratégia Európa 2020 [online]. [cit. 201406-20]. Dostupné $\mathrm{z}:$ http://ec.europa.eu/europe2020/europe-2020in-a-nutshell/targets/index_en.htm
[8] ŠKODA, J. - DOULÍK, P.: Vývoj paradigmat př́rodovědného vzdělávání. In Pedagogická orientace 3. 2009. [online]. [cit. 2014-06-25]. Dostupné na: http://www.ped.muni.cz/pedor/archiv/2009/Pe dOr09_3_VyvojParadigmatPrirodovednehoVz delavani_SkodaDoulik.pdf.

doc. PaedDr. Danka Lukáčová, PhD. Katedra techniky a informačných technológií

Pedagogická fakulta UKF v Nitre

Dražovská 4

94901 Nitra, SR

Tel: +421 376408342

E-mail: dlukacova@ukf.sk

Www pracoviska: http://www.ktit.pf.ukf.sk 